\title{
Sequence Analysis of Hypothetical Lysine Exporter Genes of Rhizobium leguminosarum bv. trifolii from Calamine Old Waste Heaps and Their Evolutionary History
}

\author{
Ewa Oleńska • Wanda Małek
}

Received: 10 November 2012/ Accepted: 18 December 2012/Published online: 16 January 2013

(C) The Author(s) 2013. This article is published with open access at Springerlink.com

\begin{abstract}
The aim of this study was to identify heavy metal detoxification system in Rhizobium leguminosarum bv. trifolii isolated from Trifolium repens inhabiting old (70-100 years) $\mathrm{Zn}-\mathrm{Pb}$ waste heaps in Poland by PCR reaction with czcD1 and czcD2 primers. By sequence analysis, four different genotypes of obtained amplicons were identified among eight examined isolates. Their sequence similarity ranged 91-99\%. They indicated the highest sequence identity to the hypothetical lysine exporter gene of $R$. leguminosarum bv. trifolii WSM1325 (91-97\%) and 76-81\% sequence similarity to hypothetical lysine exporter genes of $R$. leguminosarum bv. trifolii WSM2304 and $R$. etli CFN42 and CIAT652. On phylogenetic tree of obtained amplicons, all four studied $R$. leguminosarum bv. trifolii genotypes formed common monophyletic cluster with $R$. leguminosarum bv. trifolii WSM1325 at $100 \%$ bootstrap support showing that all four amplicons obtained in PCR with czcD1 and czcD2 primers are fragments of hypothetical lysine exporter gene (lysE). We also suggest that Lys efflux exporter may participate in heavy metal transport out of $R$. leguminosarum bv. trifolii cells.
\end{abstract}

\section{Introduction}

According to extensive human industrial and agricultural activities heavy metal content in soils still grows [23]. Some heavy metals like cobalt, copper, nickel, and zinc in

E. Oleńska $(\bowtie)$

Department of Genetics and Evolution, University of Białystok,

Białystok, Poland

e-mail: chwelat@uwb.edu.pl

W. Małek

Department of Genetics and Microbiology,

University Maria Curie-Skłodowska, Lublin, Poland small concentrations are essential to many cellular processes of microorganisms. For instance, cobalt functions as a cofactor of cobalamin and other enzymes like methionine aminopeptidase, nitrile bromopeptidase, or lysine-2,3aminomutase [11]; copper because of its convenient redox potential is essential as a prosthetic group of enzymes involved in the reduction of nitrate and nitrous oxides [24], whereas nickel is utilized for function of metal-dependent urease, carbon monoxide hydrogenase, glyoxylase, acetylcoenzyme A decarbonylase, or superoxide dismutase [13]. Behind their essential character, heavy metals are usually cytotoxic even in small quantities, they persist in the environment and are risky to all living organisms [1, 7]. Heavy metals may reduce biodiversity, significantly limit reproduction and growth as well as activity of bacteria i.e., nitrogen fixation in diazotrophs [17]. Some organisms evolved several mechanisms of resistance to cope with metals toxicity and they are tolerant to heavy metals. These mechanisms make bacteria able to survive by detoxification mechanisms developed in direct response to the metal $[3,6]$. It is thought that abilities of bacteria to tolerate toxic heavy metals might have arose due to their long-term coexistence with high heavy metals concentrations in environment shortly after prokaryote life started [9]. There are three types of toxic metals tolerance in bacteria which involve active (ATP-dependent) or passive (ATP-independent) transport of the ionic forms of metals out of the cell, enzymatic detoxification into a less toxic metal forms, and occasionally immobilization of the metal by proteins, peptides, and amino acids [12]. Proteins involved in heavy metal resistance in bacteria are chromosomally or extrachromosomally encoded [4]. So far, some metal-specific resistance pumps have been identified in bacteria i.e., ars pump for arsenic (AsIII) and antimony (SbIII), mer pump for mercury (HgII), cop pump for copper (CuII), cad pump 
for cadmium (CdII) and zinc (ZnII) resistance in Grampositive bacteria or $c z c$ pump for cadmium (CdII), zinc (ZnII) and cobalt (CoII) resistance in Gram-negative bacteria $[9,21]$.

Heavy metal contaminated areas, besides of natural origin, most often developed as the result of human activities. For example, calamine $(\mathrm{Zn}-\mathrm{Pb})$ waste heaps are highly transformed areas of extremely enormous heavy metals content in the soil, deficient in water and nutrients [25]. Such harsh edaphic conditions make metal contaminated environments highly disadvantageous for survival of various organisms like animals or plants whose biopotential could accelerate restoration of homeostasis of the disturbed places, for example through the accumulation of metals in its tissues [2]. Rhizobia are the group of Gram-negative proteobacteria that make symbiotic relationship with leguminous plants. For example, Rhizobium leguminosarum bv. trifolii forms symbiotic association with Trifolium repens (white clover) roots, and as a result nodules are formed [30]. In nodules, rhizobia fix gas nitrogen from atmosphere and convert it into ammonia, a form highly available to a host-plant improving growth of a plant and it is of great importance particularly on nutrients deficient soils of old (70-100 years) zinc-lead waste heaps like Bolesław and Olkusz ones in southern Poland. Organisms surviving in those highly difficult conditions usually are adapted to toxic heavy metals concentrations and possess genetically determined mechanisms of tolerance. In Gramnegative bacteria the ATP-independent efflux pump Czc occurs which transports zinc and cadmium ions out of the cell [15]. So far there is scarce knowledge about genetically determined mechanisms of ATP-independent heavy metal resistance in $R$. leguminosarum bv. trifolii which colonizes highly contaminated natural habitats [19]. The long-ago (70-100 years) created $\mathrm{Zn}-\mathrm{Pb}$ waste heaps as Bolesław and Olkusz are good laboratory field for studying the genetically determined heavy metals resistance mechanisms in bacteria. Therefore, the aim of this study was to identify heavy metal detoxification system in R. leguminosarum bv. trifolii isolated from $T$. repens inhabiting old (70-100 years) calamine waste heaps in Poland by PCR.

\section{Materials and Methods}

\section{Study Area}

The study was performed on metalliferous sites localized in southern Poland. As a study area in present work the old (about $70-100$ years old) $\mathrm{Zn}-\mathrm{Pb}$ waste heaps in Bolesław $\left(50^{\circ} 17^{\prime} \mathrm{N} 19^{\circ} 29^{\prime} \mathrm{E}\right)$ and Olkusz $\left(50^{\circ} 17^{\prime} \mathrm{N} 19^{\circ} 4^{\prime} \mathrm{E}\right)$ were chosen. They are inhabited by metallicollous plant populations. Average content of metals in soil of waste heaps is: 40,000 mg $\mathrm{Zn} \times \mathrm{kg}^{-1}, \quad 3,000 \mathrm{mg} \mathrm{Pb} \times \mathrm{kg}^{-1}, \quad 170 \mathrm{mg}$
$\mathrm{Cd} \times \mathrm{kg}^{-1}, 36 \mathrm{mg} \mathrm{Ni} \times \mathrm{kg}^{-1}$, and $43 \mathrm{mg} \mathrm{Tl} \times \mathrm{kg}^{-1} \mathrm{~d}$. wt. [25], whereas the highest permissible content of metals in arable lands is: $100-300 \mathrm{mg} \mathrm{Zn} \times \mathrm{kg}^{-1}, 50-100 \mathrm{mg}$ $\mathrm{Pb} \times \mathrm{kg}^{-1}$, and $0.75-1.50 \mathrm{mg} \mathrm{Cd} \times \mathrm{kg}^{-1} \mathrm{~d}$. wt. (Decree of Polish Minister of Agriculture and Rural Development 2002, 37, $334 \S 1$ ).

\section{Sampling and Bacterial Isolation}

Rhizobium leguminosarum bv. trifolii strains were isolated from the white clover root nodules collected in the heavy metals polluted fields. Bacterial isolates were obtained from six T. repens host-plants (three per one site). White clover is a clonal perennial; therefore, as separate genetic individuals they were regarded as plants with distance of 2 meters from each other. Ten nodules collected from roots of every genetic individual were sterilized, crushed, and streaked on 79CA [28]. Bacterial growth was evident after 2 days of incubation at $28{ }^{\circ} \mathrm{C}$. Single colonies were obtained by dilution method. Isolated rhizobia were confirmed for nodulation ability of common white clover plants by their inoculation in laboratory conditions. T. repens seeds at first were surface sterilized and subsequently germinated in darkness [28]. The surface sterilization of seeds was performed by treatment with $\mathrm{HgCl}_{2}(0.1 \%$; v/v) for $3 \mathrm{~min}$, washing three times with sterile water for $5 \mathrm{~min}$, once with ethanol $(70 \%$; v/v) for $3 \mathrm{~min}$ and three times in sterile water for $5 \mathrm{~min}$. After that seeds were kept in sterile water for $3 \mathrm{~h}$ for the swelling, and thereafter transferred into plates with water-agar medium and incubated in $28^{\circ} \mathrm{C}$. Twoday-old seedlings were transferred into glass tubes with Hoagland medium [8]. Seedlings were inoculated with nodule isolates directly onto the roots and cultivated in greenhouse for 6 weeks at $19-23{ }^{\circ} \mathrm{C}$ with $12 \mathrm{~h}$ of light per $24 \mathrm{~h}$ cycle for testing of the ability of forming the nodules which was estimated due to number and color of nodules and the size and color of plants. As controls non-inoculated plants were used. For further analysis in total 20 isolates of $R$. leguminosarum bv. trifolii were used.

Isolation of DNA and Analysis of Amplified Fragments

\section{Isolation of DNA}

For genomic DNA isolation, bacterial isolates were grown on orbital shaker $(190 \mathrm{rpm})$ for $24 \mathrm{~h}$ at $28{ }^{\circ} \mathrm{C}$ in $5 \mathrm{~mL}$ liquid 79CA medium [28] and after that, bacterial cultures were transferred into $25 \mathrm{~mL}$ liquid 79CA medium and still incubated in shaker during $72 \mathrm{~h}$ at $28^{\circ} \mathrm{C}$. The purity of the cultures was measured after spreading $100 \mu \mathrm{L}$ of bacteria into 79CA agar plates. The extraction and purification of genomic DNA was performed with, the usage of guanidine 
thiocyanate according to the method of Pitcher et al. [18]. The cultures were centrifuged at $20,000 \times g$ for $15 \mathrm{~min}$ and pellets were resuspensed in $200 \mu \mathrm{L}$ TE buffer $(10 \mathrm{mM}$ Tris-HCl, $1 \mathrm{mM} \times \mathrm{L}^{-1}$ EDTA, $\mathrm{pH}=8$ ). Cell suspensions were lysed with $1 \mathrm{~mL}$ GES reagent $(5 \mathrm{M}$ guanidine thiocyanate, $100 \mathrm{mM}$ EDTA, and $0.5 \% \mathrm{v} / \mathrm{v}$ sarkosyl), vortexed and incubated in room temperature for 5-10 min. The lysates were cooled on ice and $0.5 \mathrm{~mL}$ cold $7.5 \mathrm{M}$ ammonium acetate was added with mixing for $10 \mathrm{~min}$. After that $1 \mathrm{~mL}$ of chloroform and isoamyl alcohol (24:1) mixture was added. The phases were mixed and centrifuged at $20,000 \times g$ for $15 \mathrm{~min}$. Supernatants were transferred into Eppendorf tubes and $540 \mu \mathrm{L}$ of cold isoamyl alcohol was added. The samples were manually mixed for $1 \mathrm{~min}$ and cooled in $-20{ }^{\circ} \mathrm{C}$ for $30 \mathrm{~min}$. After that samples were centrifuged at $20,000 \times g$ for $15 \mathrm{~min}$. Pellets of DNA were washed three times in $100 \mu \mathrm{L} 70 \%$ ethanol and centrifuged at $20,000 \times g$ for $5 \mathrm{~min}$. The obtained DNA was dried under vacuum for $1-5 \mathrm{~min}$, resuspensed in $100 \mu \mathrm{L}$ of sterile deionized water, and redissolved overnight at $4{ }^{\circ} \mathrm{C}$. RNA was removed by addition of $2 \mu \mathrm{L}$ RNAse per sample (A\&A Biotechnology). DNA concentration and its purity was measured spectrophotometrically at $\lambda=260$ and $280 \mathrm{~nm}$ in SmartSpec ${ }^{\mathrm{TM}} 3000$ BioRad.

\section{Analysis of Amplified Sequence Fragments}

For $c z c D$ gene amplification in PCR reaction DNA with final concentration of $50 \mathrm{ng}$ DNA, 30 pmol of the oligonucleotide sequences as primers czcD1 ( $5^{\prime}$-AACCAGATCTCGCGCGA GAAC- $\left.3^{\prime}\right)$ and czcD2 (5'-CGGCAACACCAGTAGGGTC AG-3') [1], PCR DIG Probe Synthesis Kit (Roche) consisting of PCR DIG Probe Synthesis Mix, PCR Buffer with $\mathrm{MgCl}_{2}$, and enzyme in a total reaction volume of $50 \mu \mathrm{L}$ were used. Amplifications were carried out in an Applied Biosystems ThermalCycler model 2720 with the following temperature profile: initial denaturation at $94{ }^{\circ} \mathrm{C}$ for $30 \mathrm{~s}, 5$ cycles of denaturation at $94{ }^{\circ} \mathrm{C}$ for $30 \mathrm{~s}$, annealing at $54{ }^{\circ} \mathrm{C}$ for $30 \mathrm{~s}$, and extension at $72{ }^{\circ} \mathrm{C}$ for $1 \mathrm{~min}, 30$ cycles of denaturation at $94{ }^{\circ} \mathrm{C}$ for $30 \mathrm{~s}$, annealing at $64{ }^{\circ} \mathrm{C}$ for $30 \mathrm{~s}$, extension at $72{ }^{\circ} \mathrm{C}$ for $1 \mathrm{~min}$ and final extension at $72{ }^{\circ} \mathrm{C}$ for $5 \mathrm{~min}$ [16]. DNA amplicons were subjected to $1 \%$ agarose gel electrophoresis in $1 \times$ concentrated TBE buffer for $1 \mathrm{~h}$ in $100 \mathrm{~V}$ with GeneRuler $^{\mathrm{TM}} 100$ bp DNA Ladder \#SMO243 80-1,031 bp (Fermentas) as a marker. Amplified DNA was purified with "CleanUp kit" (A\&A Biotechnology). Sequencing PCR was performed by dideoxynucleotide chain-termination method (Big Dye Terminator CycleSequencing Kit Applied Biosystems) in reaction conditions as follows: initial denaturation at $96{ }^{\circ} \mathrm{C}$ for $1 \mathrm{~min}$ and 25 cycles of denaturation at $96^{\circ} \mathrm{C}$ for $10 \mathrm{~s}$, annealing at $50{ }^{\circ} \mathrm{C}$ for $5 \mathrm{~s}$ and extension at $60^{\circ} \mathrm{C}$ for 2 min. Purification of DNA after sequencing reaction was performed with ExTerminator Kit (A\&A Biotechnology) according to protocol, and sequenced with ABI Prism 3130 capillary sequencer (Applied Biosystems).

\section{Phylogenetic Analysis}

Multiple sequence alignments were performed with ClustalX [27] and corrected manually with the usage of GeneDoc software [14]. The characteristic of genotypes was performed using MEGA4 and Arlequin programs. Alignments were compared with sequences deposed in GenBank NCBI with the usage BLAST algorithm. The similarity of nucleotide sequences (\%) was calculated with GeneDoc program. Phylogenetic trees were constructed using the Neighbor-Joining (NJ) method. The phylogenetic distances were estimated with the Kimura 2-parameter (K2P) model [10] using MEGA4 program [26]. To determine the degree of statistical support for branches on phylogram, 100 bootstrap replicates of the data were analyzed.

Table 1 Polymorphic loci of sequence fragments amplified with czcD1 and czcD2 primers in four genotypes of $R$. leguminosarum bv. trifolii isolated from nodules of $T$. repens collected in Bolesław and Olkusz $\mathrm{Zn}-\mathrm{Pb}$ waste heaps

\begin{tabular}{|c|c|c|c|c|c|c|c|c|c|c|c|c|c|c|c|c|c|c|c|c|c|c|c|c|}
\hline \multirow[t]{2}{*}{ Genotype } & \multicolumn{24}{|c|}{ Number of polymorphic loci } \\
\hline & 58 & 61 & $\begin{array}{ll}64 & 103\end{array}$ & 118 & 140 & 145 & 154 & 155 & 172 & 179 & 204 & 205 & 207 & 226 & 233 & 235 & 241 & 245 & 247 & 259 & 277 & 294 & 295 & 331 \\
\hline 1 & G & $\mathrm{T}$ & C & A & G & G & G & C & A & $\mathrm{T}$ & A & G & C & A & G & $\mathrm{T}$ & G & A & A & G & A & $\mathrm{T}$ & A & C \\
\hline 2 & & & $\mathrm{~T}$ & & & & & & G & & & & & & & & & & & & & & & \\
\hline 3 & $\mathrm{~T}$ & $\mathrm{C}$ & G & G & & A & A & G & A & $\mathrm{C}$ & G & $\mathrm{C}$ & A & $\mathrm{T}$ & A & $\mathrm{C}$ & A & G & $\mathrm{C}$ & $\mathrm{C}$ & G & $\mathrm{C}$ & G & $\mathrm{T}$ \\
\hline 4 & & & & & $\mathrm{C}$ & & & & & & & & & A & & & & & & & & & & \\
\hline \multirow[t]{2}{*}{ Genotype } & \multicolumn{24}{|c|}{ Number of polymorphic loci } \\
\hline & 335 & 337 & 343 & 355 & 361 & 371 & 375 & 383 & 388 & 389 & 399 & 409 & 414 & 418 & 466 & 502 & 508 & 535 & 544 & 553 & 556 & 566 & 567 & 574 \\
\hline 1 & $\mathrm{C}$ & G & G & $\mathrm{C}$ & $\mathrm{T}$ & G & G & $\mathrm{C}$ & A & G & G & $\mathrm{T}$ & G & G & $\mathrm{C}$ & A & A & G & G & A & G & A & $\mathrm{T}$ & $\mathrm{T}$ \\
\hline 2 & & & & & & & & & & & & & & & & & & & & & & & & \\
\hline 3 & A & C & $\mathrm{A}$ & G & C & $\mathrm{C}$ & A & A & G & A & C & $\mathrm{G}$ & A & $\mathrm{T}$ & G & $\mathrm{G}$ & G & A & C & $\mathrm{C}$ & $\mathrm{C}$ & G & $\mathrm{C}$ & $\mathrm{C}$ \\
\hline 4 & & & & & & & & & & & & & & A & & & & & & & & & & \\
\hline
\end{tabular}


Table 2 Nucleotide similarity [\%] of amplified with czcD1 and czcD2 primers sequence fragments in analyzed genotypes $R$. leguminosarum bv. trifolii received from $T$. repens nodules collected in Bolesław and Olkusz $\mathrm{Zn}-\mathrm{Pb}$ waste heaps and reference rhizobia strains (GenBank database)

\begin{tabular}{lllll}
\hline & Genotype & $\begin{array}{l}\text { Genotype } \\
1\end{array}$ & $\begin{array}{l}\text { Genotype } \\
\text { ( }\end{array}$ & $\begin{array}{l}\text { Genotype } \\
4\end{array}$ \\
\hline Genotype 1 & 100 & 99 & 91 & 91 \\
Genotype 2 & 99 & 100 & 91 & 91 \\
Genotype 3 & 91 & 91 & 100 & 99 \\
Genotype 4 & 91 & 91 & 99 & 100 \\
R. leg. bv. tri. & 97 & 97 & 91 & 91 \\
WSM1325 & & & & \\
R. etli CFN42 & 79 & 79 & 76 & 77 \\
R. leg. bv. tri. & 81 & 81 & 80 & 80 \\
WSM2304 & & & & \\
R. etli CIAT652 & 79 & 79 & 79 & 79 \\
\hline
\end{tabular}

\section{Results and Discussion}

The proper function of heavy metal tolerance mechanisms improves growth of organisms living at difficult conditions particularly on high heavy metal contaminated areas which are localized for example in Poland in Olkusz region. Czc system is one of heavy metal tolerance pathways which have been evolved in bacteria. 20 isolates of Rhizobium leguminosarum bv. trifolii obtained from nodules of wild-growing $T$. repens were examined for the presence and phylogeny of the metal/ $\mathrm{H}^{+}$antiporter $c z c D$ gene whose protein product might be involved in zinc and cadmium resistance of studied bacteria isolated from Trifolium repens growing in old (70-100 years) Bolesław and Olkusz calamine $(\mathrm{Zn}-\mathrm{Pb})$ waste heaps. Using PCR with czcD1 and czcD2 primers DNA fragments of 623 -bp in length were amplified in eight of them. Four isolates were obtained from Bolesław waste-heap area (7.1, 7.2, 7.3, 7.6) and other $(8.1,8.2,8.3,8.5)$ originated from Olkusz site. The analysis of obtained amplicon sequences allowed to distinguish four genotypes among studied R. leguminosarum bv. trifolii isolates: genotype 1 (KC 145730) comprised 7.1, 7.2, 7.6 isolates, genotype 2 (KC 145731) included 7.3 isolate, genotype 3 ( $\mathrm{KC} \mathrm{145732)} \mathrm{was} \mathrm{composed} \mathrm{of} 8.1$ isolate, and genotype 4 ( $\mathrm{KC} 145733$ ) comprised 8.2, 8.3, 8.5 isolates. The comparative sequence analysis of 623-bp DNA fragments obtained in the PCR reaction of four identified genotypes revealed 49 polymorphic sites. Among 50 substitutions, 29 transitions and 21 transversions were noted. Polymorphic loci of amplified DNA fragments detected in symbionts of white clover growing in old waste heaps are presented in Table 1.

The comparison of 348-bp long amplified sequences of examined genotypes with those of reference rhizobia (GenBank database) due to BLAST algorithm revealed the highest - $97 \%$ sequence identity with the conserved hypothetical lysine exporter protein gene (LysE/YGGA) of R. leguminosarum bv. trifolii WSM1325 strain (CP 001622). The LysE/ YGGA protein product is an unidirectional efflux transporter with proton motive force and belongs to superfamily of proteins involved in transport of amino acids and heavy metals [18]. Sequences amplified in PCR reaction with the czcD1 and czcD2 primers also revealed 76-81\% identity with lysine exporter gene sequence of $R$. leguminosarum bv. trifolii WSM2304 (CP 001191), $79 \%$ identity with amino acid efflux protein of $R$. etli CIAT 652 (CP 001074) and R. etli CFN 42 (CP 000133) (Table 2). Product of the lysE gene possesses similar structure to $\mathrm{CzcA}$ protein, a member of the $\mathrm{Czc}$ system and it is possible that both of them may perform similar function. According to Diels et al. [5], ATP-dependent transporters possessing six hydrophobic domains and 12-transmembrane helix chemiosmotic transporters have the same overall structural organization and use the same class of protein in their export pathway. LysE exporter exhibits six hydrophobic domains which in a dimer form could correspond to 12-transmembrane helical spanners of the CzcA protein which arose possibly due to tandem intragenic duplication $[22,29]$. Therefore, it cannot be excluded that in $R$. leguminosarum bv. trifolii obtained from nodules of white clover which inhabited 70-100 years calamine waste heaps, LysE/ YGGA transporter functions as heavy metals exporter.

The comparative sequence analysis of DNA amplified with czcD1 and czcD2 primers revealed 91-99 \% nucleotide identity of four rhizobium genotypes obtained from root nodules of
Fig. 1 Phylogenetic NJ tree based on 348-bp fragment amplified with czcD1 and D2 primers of four genotypes of $R$. leguminosarum bv. trifolii and reference rhizobia strains (GenBank database)

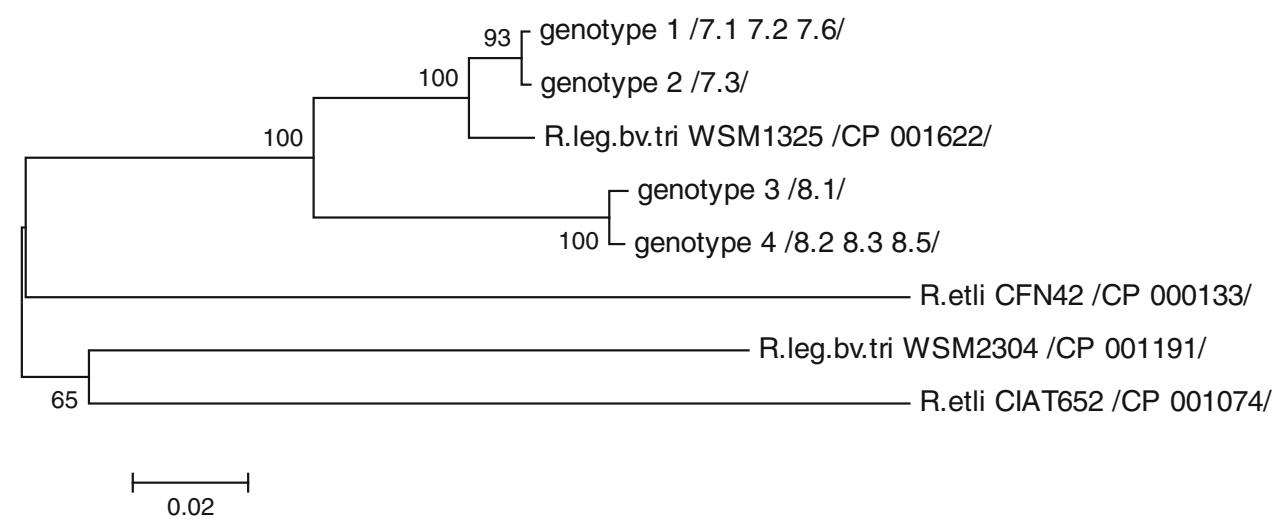


T. repens growing on old (70-100 years) $\mathrm{Zn}-\mathrm{Pb}$ waste heaps Bolesław and Olkusz (Table 2). Amplicons czcD1-czcD2 of T. repens nodule isolates from southern Poland Bolesław calamine waste heap (genotypes 1 and 2) differed from Olkusz waste-heap rhizobium isolates (genotypes 3 and 4) in $9 \%$ nucleotides. The relationship of these sequences with those of reference rhizobia is presented on Fig. 1. The phylogenetic NJ tree of $l y s E$ gene constructed on the basis of the degree of the nucleotide similarity by Kimura 2-parameter (K2P) model showed that studied rhizobium genotypes are closely related to R. leguminosarum bv. trifolii strain WSM1325, which was isolated from a nodule recovered from roots of an annual clover plant growing near Livadi beach on the Greek Cyclades island in Serifos [20]. All these genotypes formed common cluster with $100 \%$ bootstrap support suggesting that they are of monophyletic origin. $R$. leguminosarum bv. trifolii strain WSM2304 and two R. etli strains (CFN42 and CIAT653) with analyzed gene sequence identities, respectively, 80-81 and
76-79 \%, forming separate lineages with bootstrap support lower than $70 \%$ were included into analysis.

Open Access This article is distributed under the terms of the Creative Commons Attribution License which permits any use, distribution, and reproduction in any medium, provided the original author(s) and the source are credited.

\section{Appendix}

Nucleotide sequence comparison 348-bp fragment amplified with czcD1 and D2 primers of four $R$. leguminosarum bv. trifolii genotypes received from $T$. repens nodules collected in Bolesław and Olkusz $\mathrm{Pb}-\mathrm{Zn}$ waste heap with rhizobia reference strains (GenBank database). Color marking: black $-100 \%$ sequence similarity, dark gray80-99\% sequence similarity, light gray-60-79\% sequence similarity.

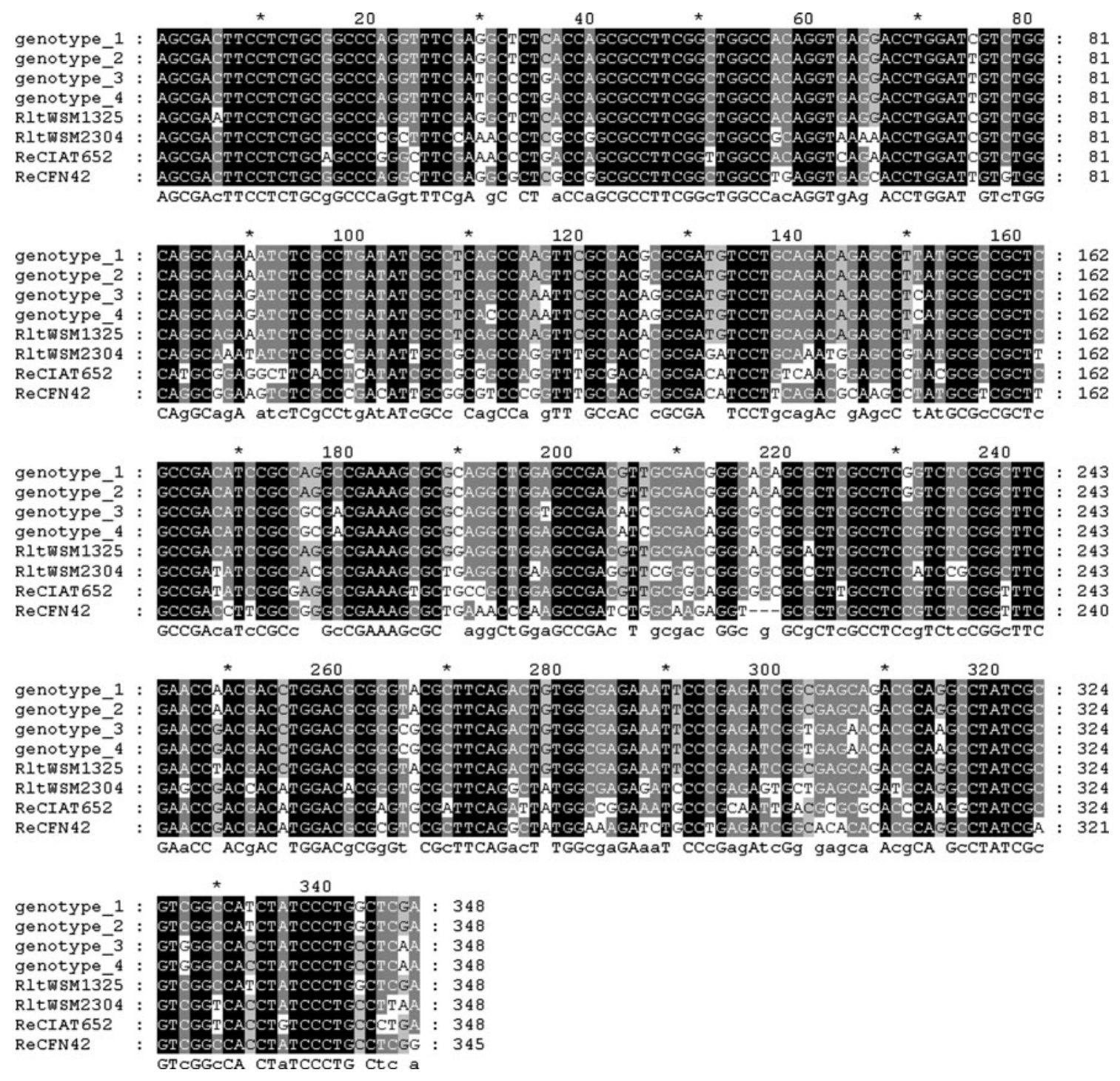




\section{References}

1. Abou-Shanab RAI, van Berkum P, Angle JS (2007) Heavy metal resistance and genotypic analysis of metal resistance genes in gram-positive and gram-negative bacteria present in Ni-rich serpentine soil and in the rhizosphere of Alyssum murale. Chemosphere 6:360-367

2. Alkorta I, Hernández-Allica J, Becerril JM, Amezaga I, Albizu I, Garbisu C (2004) Recent findings on the phytoremediation of soils contaminated with environmentally toxic heavy metals and metalloids such as zinc, cadmium, lead, and arsenic. Rev Environ Sci Biotech 3:71-90

3. Bruins MR, Kapil S, Oehme FW (2000) Microbial resistance to metals in the environment. Ecotoxicol Environ Saf 45:198-207

4. Cervantes C, Gutierrez-Corona F (1994) Copper resistance mechanisms in bacteria and fungi. FEMS Microbiol Rev 14:121-138

5. Diels L, Dong Q, van der Lelie D, Baeyens W, Mergeay M (1995) The czc operon of Alcaligenes eutrophus CH34: from resistance mechanism to the removal of heavy metals. J Ind Microbiol 14:142-153

6. Gadd G (1992) Metals and microorganisms: a problem of definition. FEMS Microbiol Lett 100:197-204

7. Glick BR (2010) Using soil bacteria to facilitate phytoremediation. Biotechnol Adv 28:367-374

8. Helder M, Strik DPBTB, Hamelers HVM, Kuijken RCP, Buisman CJN (2012) New plant-growth medium for increased power output of the plant-microbial fuel cell. Biores Technol 104:417-423

9. Ji G, Silver S (1995) Bacterial resistance mechanisms for heavy metals of environmental concern. J Ind Microbiol 14:61-75

10. Kimura M (1980) A simple method for estimating evolutionary rates of base substitutions through comparative studies of nucleotide sequences. J Mol Evol 16:111-120

11. Kobayashi M, Shimizu S (1999) Cobalt proteins. Eur J Biochem 261:1-9

12. Majáre M, Bülow L (2001) Metal-binding proteins and peptides in bioremediation and phytoremediation of heavy metals. Trends Biotechnol 2:67-73

13. Mulrooney SB, Hausinger RP (2003) Nickel uptake and utilization by microorganisms. FEMS Microbiol Rev 27:239-261

14. Nicholas KB, Nicholas HB, Deerfield DW (1997) GeneDoc: analysis and visualization of genetic variation. EMBNEW News 4:14

15. Nies DH (2003) Efflux-mediated heavy metal resistance in prokaryotes. FEMS Microbiol Rev 27:313-339

16. Nies DH, Nies A, Chu L, Silver S (1989) Expression and nucleotide sequence of a plasmid-determined divalent cation efflux system from Alcaligenes eutrophus. Proc Natl Acad Sci USA 86:7351-7355

17. Pereira SIA, Lima AIG, Figueira EMDAP (2006) Heavy metal toxicity in Rhizobium leguminosarum bv. viciae isolated from soils subjected to different sources of heavy-metal contamination: effects on protein expression. Appl Soil Ecol 33:286-293

18. Pitcher DG, Saunders NA, Owen RJ (1989) Rapid extraction of bacterial genomic DNA with guanidium thiocyanate. Lett Appl Microbiol 8:151-156

19. Reeve WG, Tiwari RP, Kale NB, Dilworth MJ, Glenn AR (2002) ActP controls copper homeostasis in Rhizobium leguminosarum bv. viciae and Sinorhizobium meliloti preventing low $\mathrm{pH}$-induced copper toxicity. Mol Microbiol 43:981-991

20. Reeve WG, O'Hara G, Chain P, Ardley J, Bräu L, Nandensena K, Tiwari R, Copeland A, Nolan M, Han C, Brettin T, Land M, Ovchinikova G, Ivanova N, Mavromatis K, Markovitz V, Kyrpides N, Melino V, Denton M, Yates R, Howieson J (2010) Complete genome sequence of Rhizobium leguminosarum bv. trifolii strain WSM1325, an effective microsymbiont of annual Mediterranean clovers. Stand Genomic Sci 2:347-356

21. Rosen BP (1996) Bacterial resistance to heavy metals and metalloids. JBIC 1:273-277

22. Saier MH Jr, Tam R, Reizer A, Reizer J (1994) Two novel families of bacterial membrane proteins concerned with nodulation, cell division and transport. Mol Microbiol 11:841-847

23. Satarug S, Baker JR, Urbenjapol S, Haswell-Elkins M, Reilly PEB, Williams DJ, Moore MR (2003) A global perspective on cadmium pollution and toxicity in non-occupationally exposed population. Toxicol Lett 137:65-83

24. Solioz M, Stoyanov JV (2003) Copper homeostasis in Enterococcus hirae. FEMS Microbiol Rev 27:183-195

25. Szarek-Łukaszewska G, Niklińska M (2002) Concentration of some chemical elements in Biscutella laevigata $\mathrm{L}$. and Plantago lanceolata L. from calamine spoils (S. Poland). Acta Biol Cracov ser Bot 44:29-38

26. Tamura K, Dudley J, Nei M, Kumar S (2007) MEGA4: molecular evolutionary genetics analysis (MEGA) software version 4.0. Mol Biol Evol 24:1596-1599

27. Thompson JD, Gibson TJ, Plewniak F, Jeanmougin F, Higgins DG (1997) The ClustalX Windows interface: flexible strategies for multiple sequence alignment aided by quality analysis tools. Nucleic Acids Res 25:4876-4882

28. Vincent J (1970) A manual for the practical study of root nodule bacteria International biological programme handbook. Blackwell Science Publications, Oxford, Edinburgh

29. Vrljic M, Garg J, Bellmann A, Wachl S, Freudi R, Malecki MJ, Sahm H, Kozina VJ, Eggeling L, Saier MH Jr (1999) The LysE superfamily: topology of the lysine exporter LysE of Corynebacterium glutamicum, a paradigm for a novel superfamily of transmembrane solute translocators. J Mol Microbiol Biotechnol 2:327-336

30. Zhuang X, Chen J, Shim H, Bai Z (2007) New advances in plant growth-promoting rhizobacteria for bioremediation. Environ Int 33:406-413 